\title{
Medical Geology: Dust exposure and potential health risks in the Middle East.
}

\author{
LYLES Mark B..$^{1 *}$, FREDRICKSON Herbert L. ${ }^{2}$, BEDNAR Anthony $\mathrm{J}^{3}{ }^{3}$, FANNIN \\ Harry B. ${ }^{4}$, GRIFFIN Dale W. ${ }^{5}$, AND SOBECKI Terrance M. ${ }^{6}$
}

\author{
${ }^{1}$ Center for Naval Warfare Studies, U.S. Naval War College, Newport, RI, 02841 USA - mark.lyles@usnwc.edu \\ ${ }^{2}$.US Environmental Protection Agency, 26 West MLK Blvd, Cincinnati, OH, 45268 USA - fredrickson.herbert@epa.gov \\ ${ }^{3}$ US Army Corp of Engineers, 3909 Halls Ferry Road, Vicksburg, MS 39180 - anthony.j.bednar@usace.army.mil \\ ${ }^{4}$ Department of Chemistry, Murray State University, Murray, KY, 42071 USA - harry.fannin@murraystate.edu \\ ${ }^{5}$ US Geological Survey, 2010 Levy Avenue, Suite 100 Tallahassee, FL, 32310 USA - dgriffin@usgs.gov \\ ${ }^{6}$ US Army Corp of Engineers, 72 Lyme Road, Hanover, NH, 45268 USA - terrence.m.sobecki@us.army.mil
}

\begin{abstract}
In the Middle East, dust and sand storms are a persistent problem delivering significant amounts of particulates via inhalation into the mouth, nasal pharynx, and lungs. The health risks of this dust inhalation are not well studied nor effectively characterized. Experiments were designed to study the chemical composition, mineral content, or microbial flora of Kuwaiti and Iraqi dust for its potential to cause adverse health effects. Multiple site samples were collected and chemical and physical characterization including particle size distribution and inorganic analysis was conducted, followed by characterization of biologic flora, including bacteria, fungi and viruses. Data indicates that the mineralized dust is composed of calcium carbonate over a matrix of metallic silicate nanocrystals and compounds containing a variety of trace and heavy metals constituting $\sim 3 \%$ of the PM10 particles by weight, of which $\sim 1 \%$ is bioavailable aluminum and reactive iron, each. Microbial analysis reveals a significant biodiversity of bacteria of which $\sim 25 \%$ are known pathogens. Of the microbes identified, several have alpha and/or beta hemolytical characteristics and show significant antibiotic resistance. Viral analysis indicates a high level of virons with RNA viruses representing a large percent. The level of total suspended particle mass at PM10 constitutes an excessive exposure micro-particulates including PM-2.5. Cell culture and animal studies have indicated a high level of toxicity to these dust particles. These data suggest that at the level of dust exposure commonly found in the Middle East, coupled with their microbial and metal content, constitute a significant health risk, both acute and chronic, to deployed troops.
\end{abstract}

Keywords: dust, health effects, heavy metals, microbes, dust exposure, dust morphology, Middle East.

\section{INTRODUCTION}

Dust can range in both composition and particle size depending on the global location. In the Middle East, dust and sand storms are a persistent problem especially during the spring and summer months. Desert sand in the Persian Gulf region consists mostly of quartz $\left(\mathrm{SiO}_{2}\right)$ but the finer dust consists primarily of clays with and without a silicate core and can be respired into the lungs due to the small size of the particle (Richards et al., 1993). The dust particles predominately consist of clays $(\sim 50 \%)$ and quartz crystals $(\sim 25 \%)$. The size distribution of airborne particles can range from $<1 \mu \mathrm{m}$ to $\sim 150+\mu \mathrm{m}$ depending on wind velocity.
Inhabitants of deserts can develop Desert Lung Syndrome, a benign, non-progressive fibrosis resulting from silica-containing dust depositing in the lungs. Desert Lung Syndrome generally develops after years of heavy exposure to sand particles (Nouh, 1989). An acute desert-related lung disease described as Desert Storm Pneumonitis was found to occur following inhalation of fine Saudi dust and pigeon droppings (Korenyi-Both, et al., 1992). In a second paper on the subject the authors describe a novel condition triggered by exceptionally fine sand of the central and eastern Saudi Arabian peninsula (Korenyi-Both, et al., 1997). They concluded that immunosuppression aggravated by opportunistic infections and other non-microbial ailments were brought on by exposure to the ubiquitous fine sand of the area causing Persian Gulf Syndrome (Korenyi-Both, et al., 1997).

Recently, a pulmonary condition termed Severe Acute Pneumonitis with unknown etiology has been reported among several U.S. military personnel deployed in Southwest Asia (Shorr AF, et al., 2004). Confirmed cases occurred during 2003 (March through August) and all cases have had bilateral pneumonitis requiring intubation and mechanical ventilation and elevated eosinophils in the lung or peripheral blood. Of the 19 cases, two have died. Four of the cases have had evidence of infections with a microbial agent. Sand inhaled into the lungs has been linked to Desert Lung Syndrome and Desert Storm pneumonitis however, it is not known if dust inhalation also leads to the development of severe acute pneumonitis. Following Gulf War I, obstructive bronchitis and bronchiolitis were reported in 86 autopsied casualties from Kuwait, with the reported observation of sand particles in lung parenchyma (Irey, 1994).

\section{METHODS AND RESULTS}

The physical and chemical properties of the Iraqi dust sample were unique among sand/dust samples normally encountered. These observations included: 1) a significant portion of the sample $(10+\%)$ was $20 \mu \mathrm{m}$ or less in size; 2$)$ these microparticulates exhibited a charge distribution that prevented them from clumping; and 3) that particles below $20 \mu \mathrm{m}$ in size seemed to contain a crystalline core surrounded by a noncrystalline inorganic coating.

The data collected and analysis of samples collected from this study produced the following observations and results:

(1) At PM10 (particle with aerodynamic mass of 10 microns), the highest hourly average each day was $2.469 \mathrm{mg} / \mathrm{m}^{3}$ 
which occurred at 0800 . Maximum exposures during dust storms exceeded $10.000 \mathrm{mg} / \mathrm{m}^{3}$. (Table 1)

(2) Daily daytime PM 10 average for 12 consecutive hours, $0700-1900$, was $\sim 0.900 \mathrm{mg} / \mathrm{m}^{3}(\mathrm{n}=12)$.

(3) At peak exposures, particle counts ( 0.5 to $10 \mu \mathrm{m}$ range) exceeded $7 \times 10^{8}$ particles $/ \mathrm{m}^{3}$.

Table 1. Particle exposure in Camp Buehring Kuwait over a 12 day period.

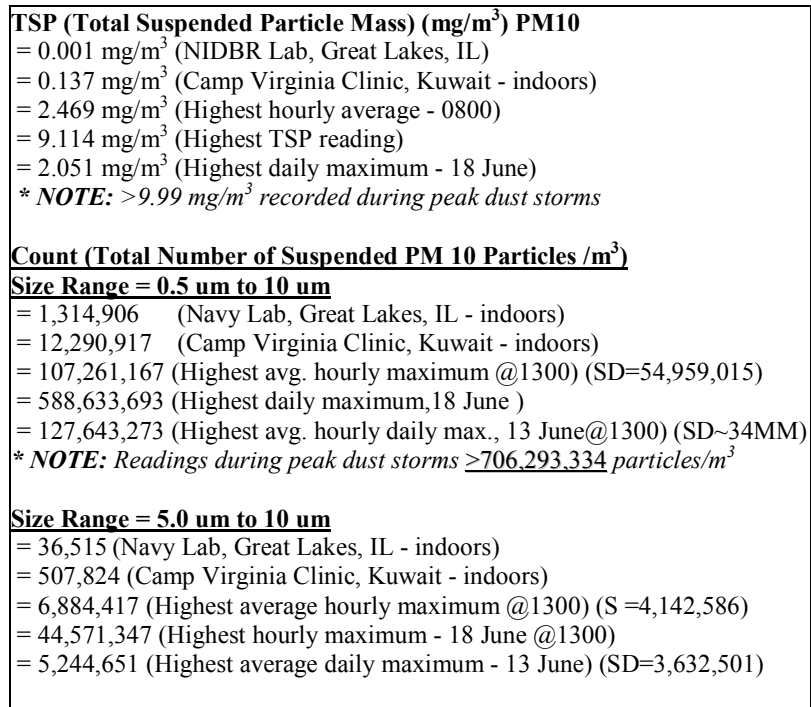

(4) A total of 54 elements were screened for with 37 different elements identified of which there are 15 are bioactive metals including Uranium. Of these the ones of greatest concern are: Arsenic (10 ppm), Chromium (52 ppm), Lead (138 ppm), Nickel (564 ppm), Cobalt (10 ppm), Strontium (2700 ppm), Tin (8 ppm), Vanadium (49 ppm), Zinc (206 ppm), Manganese (352 ppm), Barium (463 ppm), Aluminum (7521 ppm). [Sample particle results]

(5) The ratio of Chromium III to Chromium VI is unknown $\left(40-120 \mathrm{ppm}=.04-.12 \mu \mathrm{g} / \mathrm{m}^{3}\right.$ per every $\mathrm{mg} / \mathrm{m}^{3}$ of TSP mass at PM10). The US Maximum Exposure Guidelines (MEG) for Cr (III) is $12 \mu \mathrm{g} / \mathrm{m}^{3}$ and $0.068 \mu \mathrm{g} / \mathrm{m}^{3}$ for $\mathrm{Cr}$ (VI).

(6) Microbiological analysis of these same samples identified $147+$ different microbial isolates (six different Genera by 16 s DNA analysis). Of these, $\sim 30 \%$ are human pathogens, 13 are alpha and/or beta hemolytic species, and several were found to have antibiotic resistance (Figure 3). Isolates of Acinetobacter spp. and Neisseria spp. have been found inhabiting the dust.

(7) Approximately 27 fungal isolates have been identified consisting of 7 different Genera.

(8) Sterilization experiments have shown an exceptional ability for these organisms to survive.

(9) Early animal studies have suggested long-term inflammation from pulmonary exposure with mild to moderate eosinophilia.

Airborne particulates are recognized the number one health risk for troops deployed to the current theaters of operations for OIF and OEF. The DoD currently employs the EPA standard of the
Figure 1. Representative Bacteria Isolated from Dust Particles. [Colored columns indicate hemolytic characteristics.]

\begin{tabular}{|l|l|}
\hline Best ID thus Far & Comment \\
Neisseria meningiditis & meningitis \\
Staphylococcus aureus & cystic fibrosis \\
Bacillus circulans & gastro-enteritis \\
Pantoea agglomerans & septic arthritis \\
Pseudomonas agrici & \\
Ralstonia paucula & opportunist-septicemia, peritonitis, abscesses \\
Staphylococcus pasteuri & various infections \\
Arthrobacter crystallopoietes & \\
Pseudomonas balearica & cystic fibrosis \\
Paenibacillus thiaminolyticus & bacteremia \\
Bacillus vedderi & obligate alkaliphile \\
Bacillus subtilis & \\
Pantoea agglomerans & epiphyte \\
Pseudomonas pseudoalcaligenes & Strains reported to carry metallo-ß-lactamase \\
Cryptococcus albidus & septicemia and meningitis \\
Bacillus clausii & Oral bacteriotherapy \\
Kurthia gibsonii & Diarrhea \\
Bacillus firmus & alkaliphile; bread spoilage \\
Staphylococcus kloosii & various infections \\
Bacillus mojavensis & biosurfactant \\
Bacillus licheniformis & food poisoning \\
Pseudomonas oryzihabitans & Hickman catherter biofilm \\
\hline
\end{tabular}

respirable fraction $(<10 \mu \mathrm{m})$ to estimate the risk of exposure to airborne particulates. The U.S. Army Center for Health Promotion and Preventive Medicine (USACHPPM) reported that PM10 exceeded the 1-year MEG $\left(70 \mu \mathrm{g} / \mathrm{m}^{3}\right)$ for PM10 (particulate matter $<10 \mu \mathrm{m}$ ) over $97+\%$ of the time.

The scientific studies conducted supplied substantial data as to the composition of dust particles within the Kuwaiti /Iraqi sample area as well as environmental conditions and exposure potential for troops operating under these conditions. For example, during June 2004, environmental conditions were monitored from 0700 till 1900 for 12-days at Camp Buehring, Udairi, Kuwait on the Iraqi/Kuwaiti border. The average daytime temperature was $106.2^{\circ} \mathrm{F}$ with maximums in excess of $135^{\circ} \mathrm{F}$. However, surface sand temperatures elevated to $155-$ $160{ }^{\circ} \mathrm{F}$ due to the infrared (IR) radiation absorption. The average UV exposure index was $10\left(>360 \mathrm{~mW} / \mathrm{m}^{2}\right)$ and is one of the highest in the world. Average humidity was $<10 \%$ but was probably elevated over that previously reported for that region $(<3 \%)$ because of the presence of humans and other sources of water. Average daily wind velocity was approximately $14 \mathrm{MPH}(1267 \mathrm{ft} / \mathrm{min})$ with maximum wind gusts in excess of $33 \mathrm{MPH}(2800 \mathrm{ft} / \mathrm{min})$. This is significant because it physically relates not only to the amount of total suspended particle mass in the breathable air at standing height ( $\sim 2 \mathrm{~m}$ vertical), but also to the size fraction of particles being suspended $(>150 \mu \mathrm{m})$. Airborne particle dynamics determine the size of the particle airborne and the height off the deck based primarily on wind velocity and 'roughness' (drag) of the particle. Simply put, at any given wind velocity, the lower one gets to the ground the greater the mass of particles one is subjected to with an increase in particle size. Particle sizes $<44$ $\mu \mathrm{m}$ constituted from $5 \%$ to $11 \%$ of the total mass for samples collected outdoors versus indoors (tent dust) respectively. Approximately $98 \%$ of the indoor dust samples were $<150 \mu \mathrm{m}$ in diameter, while upwards of $60 \%$ of the terrestrial soil samples were $150 \mu \mathrm{m}$ or smaller in size. Under relatively low humidity conditions, these micro-particulates resist clumping and thus can remain suspended in the air for long periods. 
Therefore, normal human activity and natural wind can keep these dust particles airborne for indefinite periods of time.

\section{CONCLUSIONS}

The findings are most notable for a thorough description of the soil and particulate dust samples collected in this theater. The chemical and biological composition of the particles expands our current data. Presently, a potentially significant amount is dust is inhaled and ingested daily within the military exposure area especially during dust storms and troop movements through the desert. Most of these micro-particulates are composed of a porous silica core (crystalline metallic silicate and amorphous silica dioxide) surrounded by a type of clay (inorganic) consisting of, primarily, calcium carbonate $\left(\mathrm{CaCO}_{3}\right)$ and magnesium sulfate $\left(\mathrm{MgSO}_{4}\right)$, and metallic compounds and silicates. This inorganic coating offers varying degrees of protection to microbes from UV radiation, heat, alcohol, and oxidizing agents, and bactericidal agents. The chemistry of these particles displays a unique potential for trace metal exposure. Due to their extreme small size, these particles readily become airborne and are easily inhaled nasally $(<40$ $\mu \mathrm{m})$ and orally $(<150 \mu \mathrm{m})$ and can be deposited in deepest regions of the lungs $(<10 \mu \mathrm{m})$.

The data indicates that the mineralized dust is composed of $\mathrm{CaCO}_{3}$ in a coating over a matrix of metallic silica crystals containing a variety of trace metals constituting $\sim 1 \%$ of the PM10 by weight. The particles also consist of $\sim 1 \%$ by weight each $(10,000 \mathrm{ppm})$ of bioavailable Aluminum and reactive Iron with another $1 \%$ by weight a combination of trace and heavy metals. This finding is of specific concern due to the recent implication of Aluminum in Multiple Sclerosis and other neurological diseases. Microbial analysis reveals a significant biodiversity of bacterial, fungi, and viruses of which $\sim 30 \%$ are pathogens. The level of total suspended particle mass along with environmental \& physiological conditions present constitute an excessive exposure to micro-particulates including PM $2.5 \&$ the potential for long-term adverse health effects. These data suggest that the level of dust exposure coupled with the microbial \& bioavailable metal content could constitute a significant health risk. When taken with other existing work suggest that further immediate research is warranted to provide insight into potential human health risks both acute and chronic.

\section{REFERENCES}

A.F. Alshubaili, K. Alramzy, Y.M. Ayyad, and Y. Gerish, "Epidemiology of Multiple Sclerosis in Kuwait: New Trends in Incidence and Prevalence," Eur. Neurol., vol 53, p.p.125-131, 2005.

N.S. Irey, "Kuwait Casualties: Morphologic and Toxicologic Findings," NIH Technical Assessment Statement, April 27-29, 1994.

A.L. Korenyi-Both, A.L. Korenyi-Both, A.C. Molnar, and R. Fidelus-Gort, Al Eskan disease: Desert Storm pneumonitis, Mil. Med., vol 57(9), p.p.452-462, 1992.
A.L. Korenyi-Both, A.L. Korenyi-Both, and D.J. Juncer, "Al Eskan disease: Persian Gulf syndrome,” Mil Med., vol 162(1), p.p.1-13, Jan.1997.

A.L. Korenyi-Both, and A.C. Monlar, "Al Eskan disease: Desert storm pneumonitis,” Mil. Med. vol158, p.p.A6, 1992.

M.B. Lyles, H.L. Fredrickson, A.J. Bednar, H.B. Fannin, and T.M. Sobecki, "The chemical, biological and mechanical characterization of airborne micro-particulates from Kuwait," Abstract 8th Annual Force Health Protection Conference, Session 2586, Louisville, KY, 2005.

M.B. Lyles, H.L. Fredrickson, H.B. Fannin, A.J. Bednar, D. Griffin, and T.M. Sobecki, "The Chemical, Biological, \& Physical Characterization of Dust Particulates from the Middle East," Chinese Journal of Geochemistry, vol 25 (Suppl.1), p.p. 2-3, March, 2008.

Morbitity and Mortality Weekly Report (MMWR)."Severe acute pneumonitis among deployed U.S. military personnel in Southwest Asia," vol 52, p.p.857-859, March-August 2003.

M.S. Nouh, "Is the desert lung syndrome (non-occupational dust pneumoconiosis) a variant of pulmonary alveolar microlithiasis? Report of 4 cases with review of the literature," Respiration, vol 55(2), p.p.122-126, 1989.

A.L. Richards, K.C. Hyams, D.M. Watts, P.J. Rozmajzl, J.N. Woody, and B.R. Merrell, "Respiratory disease among military personnel in Saudi Arabia during Operation Desert Shield," Am. J. Public Health, vol 83, p.p. 1326-9, 1993.

A.F. Shore, S.L. Scoville, S.B. Cersovsky, G.D. Shanks, C.F. Ockenhouse, B.L. Smoak, W.W. Carr, B.P. Petruccelli, "Acute eosinophilic pneumonia among US military personnel deploying in or near Iraq," JAMA vol 292, p.p.2997-3005, 2008 . 


\section{ADDENDUM}

Bioavailable Elements in Dust Particles from Camp Buehring, Kuwait. [NOTE: Strontium at 2436 PPM, Lead is 138 PPM, Nickel is 564 PPM, and Aluminum 7521 PPM.

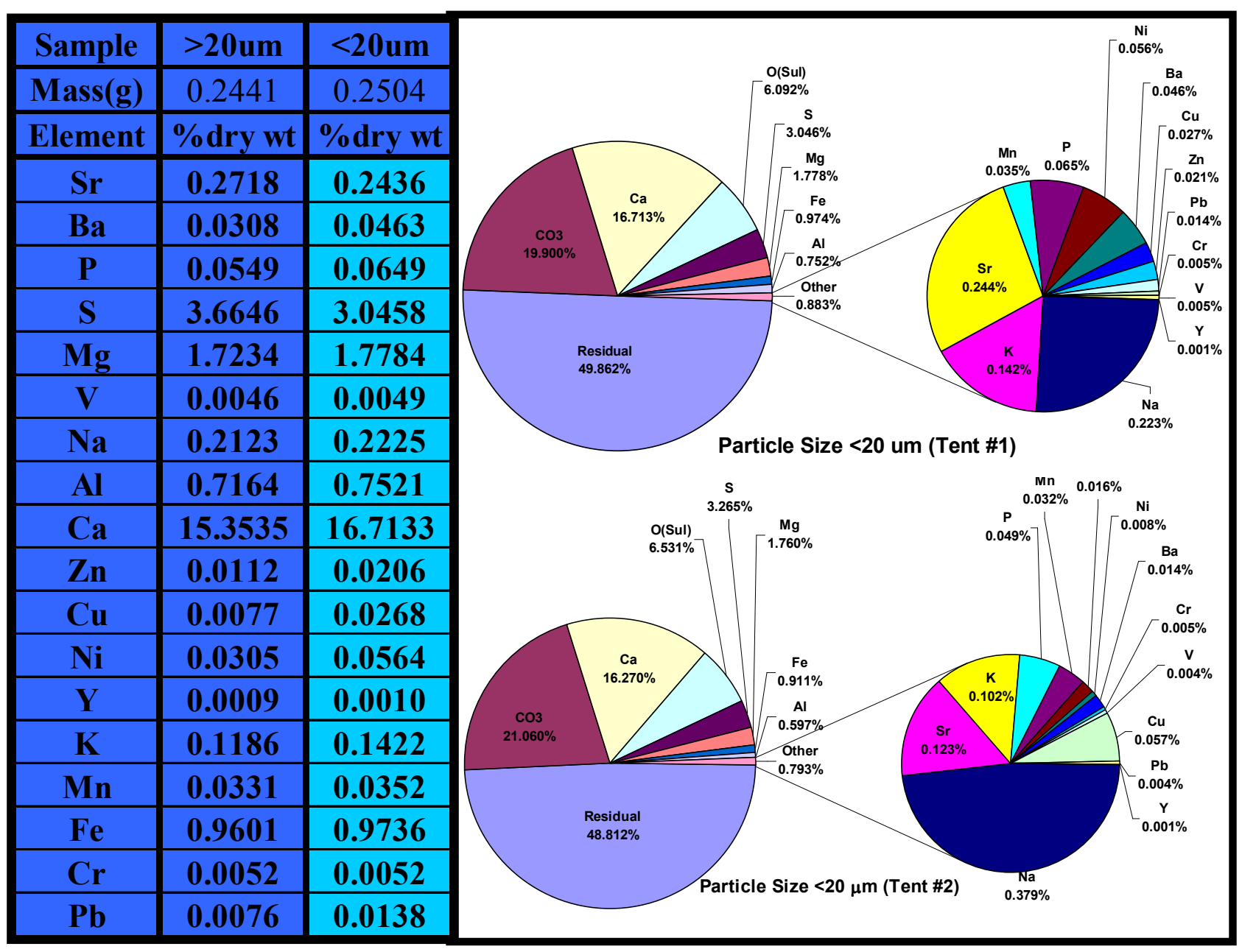

